\title{
Making beliefs explicit - student teachers' identity development through personal practical theories
}

\section{Maaranen, Katriina}

2020-05-26

Maaranen , K \& Stenberg , K 2020 , ' Making beliefs explicit - student teachers' identity development through personal practical theories ' , Journal of Education for Teaching , vol. 46 , no. 3 , pp. 336-350 . https://doi.org/10.1080/02607476.2020.1749994

http://hdl.handle.net/10138/336769

https://doi.org/10.1080/02607476.2020.1749994

acceptedVersion

Downloaded from Helda, University of Helsinki institutional repository.

This is an electronic reprint of the original article.

This reprint may differ from the original in pagination and typographic detail.

Please cite the original version. 


\title{
Making Beliefs Explicit - Student Teachers' Identity Development through Personal Practical Theories
}

Katriina Maaranen and Katariina Stenberg

University of Helsinki, Faculty of Educational Sciences

\begin{abstract}
This research focuses on the identity development of ten student teachers during a one-year Teacher's Pedagogical Studies program in Finland. The students wrote narratives that represented their beliefs of "good" teaching, and in this study, these beliefs are called as personal practical theories (PPTs). After two teaching practicum experiences, the students were interviewed about the realization of their PPTs. The most significant change, based on both the narratives as well as the realized PPTs, was related to contextual factors (such as collaboration with school members and shared organizational culture) that became increasingly significant as teacher education proceeded, which may narrow the potential gap between the student teachers' ideals and the real world of the schools. Based on the results, we see that it is extremely important that future subject teachers should have the opportunity to focus on topics that fundamentally affect their forthcoming work, that is, their personal images, ideals, and values regarding teaching.
\end{abstract}

Keywords: teacher education, personal practical theories, teacher identity, subject teachers

\section{Introduction}

According to Crosswell and Beutel (2017), development as a teacher is a product of the continuous, dynamic, and reciprocal interactions of the preservice teacher and her/his experiences within multiple contexts during teacher education (p. 418). There are many aspects of a teacher's professionalism to be developed during his/her education, such as knowledge (e.g. Darling-Hammond 2006; Darling-Hammond and Bransford, 2005; Shulman 1986; 1987), competences (e.g. Hiebert et al. 2007; Pantic and Wubbels 2010; Pantic et al. 2011), and teacher identity (e.g. Atkinson 2004; Trent 2011; Sachs 2005; Day, Kington, Stobart and Sammons 
2006; Akkerman and Meijer 2011). The importance of orientation and understanding it in the professional identity construction are also key factors for commitment and retention to teaching, as well as understanding the stability or instability of teacher identity (Hsieh 2015; Day, Elliot and Kington 2005; Day et al. 2006).

Teacher identity is interesting for researchers in teacher education (see, e.g. Atkinson 2004; Rodgers and Scott 2008), and according to Avraamidou (2014), this topic offers a comprehensive construct for understanding teachers' development and learning. Furthermore, according to Sachs (2005), through teacher identity teachers can construct their professionalism, its place in society, and enhance their professional development. Furthermore, there is a connection between teacher identity and motivation, satisfaction, and commitment to work (Day, Kington, Stobart, and Sammoms 2006). Thus, it can be argued that development of teacher identity is significant for teachers and student teachers.

This research focuses on the identity development of students becoming subject teachers during one year of their pedagogical studies and we are particularly interested in the point of view of their PPTs. The data were collected from ten Finnish student teachers while they participated in the Teacher's Pedagogical Studies programme, which is a mandatory part of a teacher's qualification in Finland. The students represent different main subjects, and they usually participate in these studies during the $3^{\text {rd }}$ or $4^{\text {th }}$ year of their university courses. The student teachers expressed their PPTs about "good" teaching in short narratives written twice during their pedagogical studies. Additionally, they were interviewed twice after their teaching practice (practicum) experiences. The two research questions of this study are:

1. What changes appear in student teachers' PPTs during their teacher education?

2. How are the student teachers' PPTs realized in their teaching practice experience?

\section{Theoretical framework}

\section{Beliefs as a Basis for Teacher Identity}


After decades of research, it is still viewed as important to research beliefs and belief systems in teacher education. Beliefs can be defined as understandings or premises that are personally felt to be true (Richardson 1996). Sanger (2017) states that it may seem obvious for some that what a teacher believes will influence what she does. By beliefs, Sanger means beliefs about herself and her students, the content of the curriculum, and/or the relative value of the courses of action she might take in her classroom. By influence in action, Sanger refers to what she does, the motivation and manner in which her actions are carried out, as well as the quality of her experience in doing so and its role in future practice. However, Sanger reminds us that what influences what and how this occurs, has long been a subject of debate (339-230). Furthermore, beliefs involve some cognitive content and in addition: many descriptions also include some sort of affective loading toward that cognitive content (approval, endorsement, or commitment), conscious or otherwise (Sanger 2017, 340). Fives and Buehl (2012) suggest that beliefs serve three functions relating to practice: (a) filters for interpretations, (b) frames for defining problems, and (c) guides or standards for action (478). Fives and Buehl (2012) have argued that given the preponderance of evidence, it makes sense to move beyond the question of whether or not teacher beliefs influence practice and whether teacher education can change them, to asking in more refined and systematic ways which teacher beliefs are elated to various practices, how those beliefs play a role in practice (e.g. as filters, frames and guides), and what in turn influences the complex interactions of beliefs and action in the context of teaching practice and in teacher education. (Sanger 2017, 343)

Richardson (2003) points out that a critical factor for success includes the process of making held beliefs explicit, what is the aim of this current study. She emphasizes an active and engaging dialogue between beliefs held by teachers and those espoused in a program of study, all carried out in the context of relevant practice (real or represented in case studies or simulations) (Richardson 2003). When student teachers enter a teacher education programme, their developing teacher identities already hold various beliefs regarding a teacher's work based on their own experiences as students (Levin, He, and Allen 2013). According to Tilson et al. (2017, 455) teachers' pedagogical beliefs guide and shape their classroom practice, and if left unspoken they may be resistant to change (Korthagen 2010). In this study, we describe pedagogical beliefs as personal practical theories (PPTs) that guide and shape teachers' classroom practice (Tilson et 
al. 2017; He and Levin 2008; Chant 2002). In the next section, we will illustrate how PPTs can be explored in practice by using Herbart's (1835) Didactic Triangle.

\section{PPTs in a Didactic Triangle}

PPTs that form the basis of teacher identity may be explored with the help of Herbart's didactic triangle, which is usually exemplified with teacher, student, and content as its three points. It is suitable for demonstrating specific aspects of teachers' work, because the three elements are equal. The matters that relate to teachers include the teacher's personal history and education. The matters that relate to students are, for instance, growth, learning and social interaction and the content contains curriculum, but is not restricted to that, but instead contains all content that is included in teaching. All the elements are of utmost importance to a teacher's professional work. The triangle includes not only the elements in the points, but also the relationships between the elements. The relationship between teacher and the student is called the pedagogical relationship. The content relationship is the relationship teacher has with the content. The didactic relationship is the relationship teacher has with the student's relationship to the content. In other words, the teacher is trying to have an effect on the student-content relationship and the learning process, aiming to achieve understanding. However, the didactic triangle must be considered as a whole. This means that there are other relationships besides those previously mentioned. The teacher has a relationship with him/herself, reflecting their qualities. The teacher considers wider essential issues, for example values concerning the profession. Furthermore, teaching is always context-bound; teachers are, for example, a part of a school community and society and thus there is a context relation between a teacher and contexts. (Kansanen 2003; Stenberg et al. 2014.) Teacher identity may be explored with the help of PPTs relating to these relationships (see Figure 1)

\section{Figure 1. Here}

\section{Context, Methods, Data, and Analysis}




\section{Finnish teacher education}

This qualitative case study was carried out in Finland, where teacher education is research-based, and all teachers graduate with a master's degree (see e.g. Tirri 2014; Sahlberg 2011; Niemi, Toom and Kallioniemi 2016). Subject teachers major in their future teaching subject and study approximately 3-4 years, i.e. at least to the bachelor's level of their major subject before applying to the Teacher's Pedagogical Studies programme. One year (60 study points) of pedagogical studies for subject teachers includes, for instance, pedagogical, psychological and philosophical studies, as well as practicums.

Teachers’ Pedagogical Studies are a qualification requirement for Finnish teachers, but additionally they need to have a major subject and a minor subject in at least one Finnish school subject. Typically, subject teachers teach grades 7-12 in the Finnish school system. Grades 7-9 are part of comprehensive school (middle school) and grades 10-12 are part of optional upper secondary school (high school).

\section{Participants}

The participants in this study were ten student teachers (Table 1). Students were contacted via email and a short recruitment pitch talk during one of the very first lectures of their Teacher's Pedagogical Studies, into which 434 students had registered. The students were encouraged to participate, emphasizing that they would be investigating their own teacher development. As the participation in this study may have seemed a hefty task, and a commitment to a one-year follow-up study quite a lot to be asked, the researchers were satisfied that these ten students volunteered to participate in this one-year study. It was of the utmost importance that all participated out of their own interest.

\section{Table 1. Here}

The students completed the Basic Practicum in November-December 2015 and the Advanced Practicum in March-May 2016 (however, three students attended one year later). Most of the 
practicums took place in the University Teacher Training Schools, but some were also held in field schools.

\section{Data Sources}

This research presents a qualitative case study of ten students at one university. The data comprise 20 written narratives and 20 audio-recorded semi-structured interviews.

\section{Written narratives}

The data comprise narratives that ten student teachers wrote twice during their studies. The task of the narrative was to write about the "ideal teacher," and the assignment stated that the student was supposed to write what was important in teaching and school work for him/her and why. The first narrative was written at the very beginning of the studies. One of the researchers identified PPTs by finding the core meaning of the narratives. The second narrative was written in the middle of the studies, in January-February, and again the second researcher identified the PPTs communicated in the essays.

\section{Interviews}

Of these ten students, seven participated in the research project during the intended one-year study, 2015-2016. Three students had a gap year 2016, which meant that they returned to study their major subjects and came back to finish their pedagogical studies at the beginning of 2017. The first interviews were conducted after the Basic Practice in December 2015, and the focus of the interview was the realization of the PPTs in the practicum. The second interview was held after the Advanced Practice in April-May and, again, it focused on the realization of the PPTs in the practicum. In the interview, the participants were asked which of their written PPTs were realized and how (examples of their practice), and which were not realized, and why. The participants gave real-life examples of their experiences in the practicum, which illustrated a certain PPT.

The total amount of data was, thus, 20 narratives (PPTs) and 20 interviews. 


\section{Data Analysis}

\section{The written narratives}

To answer the first research question, personal practical theories were analysed using the theoretical framework (Figure 1.) inspired by the work of Pennington and Richards (2016) and Stenberg et al. 2014.) The beliefs of the student teachers' practical theories were coded using a system derived from the essential relationships in a teacher's everyday work (Figure 1), which is explained in the theoretical framework. According to the classification of each belief in the student teachers' practical theories, five main relation-categories emerged: (1): Self-awareness (Teacher- relation), (2) Content relation, (3) Didactical relation (4) Pedagogical relation (5) Context relation. Altogether, 129 beliefs were coded, of which 78 were produced at the beginning of the studies and 51 in the middle of their studies.

\section{The interviews}

The interview data were analysed using theory-driven content analysis (Elo and Kyngäs 2008; also Dey 1993) in order to answer the second research question. The didactic triangle (Figure 1) including the relationships that are explained in the theoretical framework of this article, was used as the theoretical frame for analysis of the interview data. In order to organize the data, the first step of the analysis was to reduce the data; then, categorize them based on the realization of the PPTs and, finally, according to the theoretical frame of didactic triangle. The excerpts presented in the results section were selected to represent and illustrate the particular category in the best possible way.

\section{Results}

Student teachers' written personal practical theories illustrate identity development

The personal practical theories were analysed using the theoretical framework inspired by the work of Pennington and Richards (2016) and Stenberg et al. 2014.). The results (Table 2) show that the greatest changes in the teacher identity of student teachers during their studies emerge in the pedagogical relation (change $-12.9 \%)$ and the context relation $(+13.8 \%)$. The lowest changes, 
in turn, appear in self-awareness (teacher relation) (change $+4.4 \%$ ), content relation (change $2.49 \%)$ and didactical relation $(-3.54 \%)$.

\section{Table 2. Here}

The results denote that the teacher identities of student teachers strongly reflect issues concerning self-awareness and pedagogical interaction between teacher and students. Teaching is viewed through individual values, ideals and qualities and the collaboration with students and their welfare is of high importance. However, a noticeable change in the pedagogical relation occurred; the relation diminished strikingly during the studies. Instead, the context position increased and the environmental aspects of a teacher's work were emphasized more in the middle of the studies. From this it may be concluded that the more experience student teachers attain, the more they become aware of the contextual factors that influence their work. The most surprising result was the low emphasis of the content relation in the developing teacher identities of student teachers. In other words, the specific knowledge of the content they teach is not the main focus. Instead, the way they want to see themselves and act as a teacher are most essential, and the selfawareness (teacher relation) was a high priority in their teacher identity throughout the studies.

\section{Student Teachers' Reflections on the Realization of PPTs in the Practicums}

\section{Realization of PPTs in the Basic Practicum}

All students reported that some of those issues that they considered important (practical theories) were realized in the Basic Practicum. Some of them were single events that they remembered, while others were more frequent. In total, the students reported that realization had taken place in the practical training period 29 times (41\%). All but one student reported that there were occasions where they were able to see their practical theories partly being realized. The students mentioned that these important issues, i.e. practical theories, were realized somewhat a total of 25 times $(36 \%)$. They were able to trace some kind of success or some events where they were partly successful in realizing the PPTs. In total, $77 \%$ of their PPTs were realized on at least one occasion in the Basic Practicum. 
However, eight students reported 16 occasions during which the PPTs were not realized at all (23 $\%)$. We were particularly interested to know why the students' personal practical theories were not realized in the Basic Practicum. Ultimately, the reasons varied significantly, but the one reason that was most frequently mentioned, cited six times, was the short period of time. For example, Student 4 had a personal practical theory about helping people to their full potential. She aimed for this in the Basic Practicum but experienced it as too a short time to reach such a goal. She also had the feeling that the pupils were not as enthusiastic about the topic as she was.

Being a novice in teaching was mentioned five times. For instance, Student 3 wanted to provide all students with the best possible environment for learning. She held lessons for both lower and upper secondary students. She stated that $75 \%$ of her time with lower secondary students was used on disciplinary matters. Conversely, her experience of the upper secondary students was such that they were so quiet and calm that she suspected that they would have learned the content, no matter what the quality of the teaching. Furthermore, she reported feeling that, as a novice, she did not have the required authority to deal with disciplinary issues, but she also suspected that her physical appearance or problems with her voice affected this. She additionally stated that she did not know her rights or duties well enough, which, for instance, became clear when she tried to confiscate a pupil's mobile phone due to disruptive behaviour.

Circumstances in four cases were such that either the student teachers did not face such situations, or they were unable to make happen something that they would have wanted. One example of this was a PPT by Student 7: she wanted to be part of the working community, and she envisioned the community to be active, development-minded, and social. This was not realized, because the student teachers were unable to be in contact with the regular staff.

\section{Realization of PPTs in the Advanced Practicum}

Twenty-three of the PPTs were realized in this practicum (43\%). Another 22 times the PPTs were realized partly, or somewhat (42\%). In total, $85 \%$ of the PPTs were realized at least on occasion in the Advanced Practicum. For six students, the PPTs were not realized (15\%). Three of these cases were caused because of the circumstances of the practice or the school, three 
because the practice period was so short, and one because the student was still in the early stages of learning to become a teacher, i.e. being a novice.

\section{Cross-case analysis: Realization of Practical Theories in the Didactic Triangle}

In order to discover what issues the realized PPTs dealt with, we decided to analyse them according to the didactic triangle (Figure 1), adopted from Herbart. For this purpose, we combined the PPTs that were realized well and partly.

\section{Basic Practice Experiences According to the Didactic Triangle}

The results (see Figure 2) show that in the Basic Practicum most of the students' realized PPTs related to the didactical relationship (37\%). In other words, the students explained what kinds of actions they took in order to have an effect on their relationship to the content. For example, student 5 described in her PPT that she considers it important that the teacher listens and observes the pupils in order to be able to choose the best methods for them, and they can vary depending on the group or other matters. She described a situation where she had made a plan for a lesson which was supposed to be executed twice with two different groups. For the other group this plan worked very well, and the lesson went well in her opinion, but for the other group it did not:

There weren't radical differences between the groups, but the class on Monday morning at 8 was stiffer than the one on Friday afternoon. So on Monday I had to try to wake them up, motivate and encourage, and on Friday afternoon I had to cool them down a bit.

The second largest category was the pedagogical relationship. This was mentioned in $33 \%$ of the realized PPTs. One example of this is described by student 4, who considers it as very demotivating if the student feels him/herself as stupid or insufficient. In the practicum she tried to notice the students in a positive way:

Well I tried to praise students whenever there was even a small reason for it, and especially those for whom school is difficult, and they feel that they cannot do these things. So then I try to make something out of nothing, like Wow, great, you completed 
one part of this assignment, or Great, you were able to sit quietly at your place for the entire class!

Twenty-two per cent of the realized PPTs focused on the student teacher him/herself. This category of the triangle consists of thoughts that relate to "I as a teacher". For example, student 6 wants to develop in the same style as she has as a mother: she wants to provide boundaries but also love. She experienced that this was challenging in the practicum, even though she had the feeling that she had succeeded in this, and had gotten good advice for it:

We had this one supervisor... she said that she always considers a new student group as a nice group with nice students. It was important to me, because I realized, that if there is a group in the school, of which all the teachers are talking about, that it is a difficult group... I realized that I couldn't go in front of them thinking that they are the enemy.

Only 5\% of the realized PPTs related to the content relationship, in other words, the relationship between the teacher him/herself and the content. One example of this is Student 2, who considers that the main characteristic of a teacher is his/her subject knowledge. She received feedback from her students in the practicum that she knew the contents well and was professional. Finally, only $2 \%$ of the realized PPTs related to matters dealing with content or context.

Figure 2. Here

\section{Advanced Practice Experiences According to the Didactic Triangle}

The realized PPTs in the Advanced Practicum had a somewhat different emphasis compared to the Basic Practicum (see Figure 3). The largest category was the pedagogical relationship. This was mentioned in $30 \%$ of the realized PPTs. The second largest category was the teacher, with $25 \%$ of all realized PPTs belonging to this category. The didactical relationship was realized in $23 \%$ of the PPTs, which is significantly less than in the Basic Practicum. One category that was almost invisible in the Basic Practicum emerged much more in the Advanced Practicum, that is, the context. $16 \%$ of the realized PPTs dealt with the context of teaching. As in the Basic Practicum, the number of PPTs realized relating to the content-relation issues was only $4 \%$. 
Finally, the content category accounted for only $2 \%$ of the realized PPTs, which was exactly the same as in Basic Practicum.

Figure 3. Here

\section{Differences between the Basic and Advanced Practicums}

The greatest difference between these two practicum experiences was the decrease of didactical relationship from $37 \%$ to $23 \%$. Another significant change was the notable increase in the context-category, from $2 \%$ to $16 \%$. There was a slight decrease in the pedagogical relationship $(33 \%=>30 \%)$ and also a slight increase in the teacher's self-awareness from $22 \%$ to $25 \%$.

If we look at the increases in the context category and the teacher's self-awareness, we could suspect that these changes are linked to an increased awareness of the teacher's work, the school and education in the society, as well as the teacher's societal role. The decrease of the didactical relationship category is more difficult to explain.

What is compelling, in our opinion, is that the subject both in terms of the teacher-content relationship, as well as the role of the content, plays such a small role in these students PPTs and, thus, also in their realization. As they are becoming subject teachers, is it so integral or selfevident a part of their work and identity?

\section{Discussion and Conclusions}

The aim of this research was to explore what happens in student teachers' personal practical theories during their one year in the Teacher's Pedagogical Studies program. The most significant change, based on both the narratives as well as the realized PPTs, was in the context relation. This is an important finding and gives us hope as teacher educators. According to our results, it may be concluded that contextual factors become progressively significant as teacher education proceeds. Awareness of the essential elements in the teaching environment (for example, the importance of collaboration with school members, the collaborative support, shared 
rules, shared organizational culture) may, at best, narrow the potential gap between the student teachers' ideals and the real world of the schools. It is particularly interesting that these results conflict with those of our most recent study, in which we compared the PPTs of beginning and advanced elementary school student teachers (Stenberg and Maaranen, accepted). In the elementary school student teachers' PPTs, the context category was nearly invisible. Therefore, even though Finnish teacher education is continuously presented as highly successful and effective (see Darling-Hammond 2017; Sahlberg 2011; Tirri 2014), we cannot close our eyes to needs for development.

Future subject teachers' teacher identities play a pivotal role in how they interpret experiences during their initial teacher education. Great emphasis is placed on the way they want to see themselves as teachers, and this is based on their practical theories. Among other qualities, inspiration, respectfulness, fairness, and responsibility play a crucial role in their teaching. On one hand, this is an unsurprising result; however, it raises the question of the idealistic view of teachers' work. Although it is important to be aware of the moral nature of teaching, such high ideals may create an obstacle for seeing the complex nature of the teachers' work. This result is in line with our previous studies in which the group of participants were elementary school student teachers (Maaranen and Stenberg 2017; Maaranen et al. 2016; Stenberg et al. 2014). In a study by Anspal, Leijen and Löfström (2018) organizational support for reflecting on tensions that are experienced during initial teacher education, is the key to identity development. Consequently, in subject teacher education, student teachers should have the opportunity to focus on topics that fundamentally affect their future work, that is, their personal images, ideals, and values regarding teaching.

The most surprising result was the relatively small emphasis on the content relation in student teachers' PPTs. This may indicate that, since the students have chosen to become subject teachers, they orient themselves as teachers and matters concerning teaching are in the primary focus of their teacher identity.

Most of these student teachers' personal practical theories were realized at least on one occasion during the practicum experiences. We can say that mostly, the students were able to trace their actions to their pedagogical beliefs. This is extremely important because, as mentioned before, the student teachers need to be able to articulate their beliefs and analyse their effect on their 
actions, as well as become aware of themselves (cf. Korthagen 2010). Also Nickel and Zimmer's (2018) study shows that the shift from 'ideal self' to 'actual self' occurred primarily in the practicum experiences. Toom, Husu and Patrikainen's (2014) study also showed that student teachers were capable of using different forms of reflection when analysing their teaching experiences and practical knowledge of it. However, in a study by Prilop, Weber and Kleinknecht (2019) one of the conclusions was that not all types of reflection are beneficial. According to them, reflection and feedback environments with video support seemed to maintain constructivist beliefs productively, whereas text-based environments fostered traditional beliefs (Prilop, Weber \& Kleinknecht, 168). Helping the students in this process is one of the tasks of teacher education (Richardson 2003; Fives and Buehl 2012; Sanger 2017).

Kostiainen et al., $(2018,66)$ claim that "understanding students' experiences of meaningful learning in teacher education is central to developing emotionally, relationally, and morally sound pedagogical practices." Moreover, the continuous development and dynamic nature of education is essential in today's fast-changing world, and high-quality teaching requires the teacher to be able to understand and navigate social and political structures (see Maclellan 2017). Korthagen (2017) puts critique towards the assumption in teacher education that only teacher thinking guides teacher behaviour. For Korthagen, professional development is an entanglement of the professional and personal and thus, learning to teach cannot be separated from the person (see also Hamacheck 1999). In order to educate skilful teachers to teach skilful learners in tomorrow's unpredictable world, student teachers should be able to become aware of the ways their personal practical theories transfer into actual teaching practice and furthermore their ability to 'make holistic judgements, i.e. 'to deal wisely with particular situations in the course of teaching' (Lunenberg and Korthagen 2009, 226). We consider the effectiveness of teacher education as not only limited to the previously mentioned aspects of professional knowledge and professional practice, but also in the context of becoming a strong and solid teacher, in other words, one who possesses clear teacher identity and self-esteem. Teacher educators need to know who their students are and what beliefs they have. In our opinion that is the only way better to prepare the student teachers for their future careers. The importance of understanding and explicitly addressing the beliefs of student teachers is as a fundamental part of teacher education (Richardson 2003). 


\section{References}

Akkerman, S. F., and P. C. Meijer. 2011. "A Dialogical Approach to Conceptualizing Teacher Identity." Teaching and Teacher Education 27 (2): 308-319. http://dx.doi.org/10.1016/j.tate.2010.08.013

Alsup, J. 2006. Teacher Identity Discourses. Negotiating Personal and Professional Spaces. Mahwah, NJ: Lawrence Erlbaum.

Anspal, T., Ä. Leijen, and E. Löfström. 2018. “Tensions and the Teacher's Role in Student Teacher Identity Development in Primary and Subject Teacher Curricula." Scandinavian Journal of Educational Research 63 (5): 679-695. DOI:0.1080/00313831.2017.1420688

Atkinson, D. 2004. "Theorising How Student Teachers Form Their Identities in Initial Teacher Education.” British Educational Research Journal 30 (3): 379-394. doi.org/10.1080/01411920410001689698

Avraamidou, L. 2014. "Studying science teacher identity: current insights and future research directions." Studies in Science Education 50 (2): 145-179. doi:org/10.1080/03057267.2014.937171

Beijaard, D., and N. Verloop. 1996. “Assessing Teachers' Practical Knowledge.” Studies in Educational Evaluation 22 (3): 275-286. https://doi.org/10.1016/0191-491X(96)00016-8

Beijaard, D., P. Meijer, and N. Verloop. 2004. "Reconsidering Research on Teachers' Professional Identity." Teaching and Teacher Education 20 (2): 107-128. doi:10.1016/j.tate.2003.07.001

Chant, R.H. 2002. "The Impact of Personal Theorizing on Beginning Teaching: Experiences of Three Social Studies Teachers." Theory and Research in Social Education 30 (4): 516540. doi.org/10.1080/00933104.2002.10473209

Cohen, J. L. 2008. “'That's not Treating you as a Professional': Teachers Constructing Complex Professional Identities through Talk." Teachers and Teaching 14 (2): 79-93. doi.org/10.1080/13540600801965861

Crosswell, L and Beutel, D. 2017. " $21^{\text {st }}$ century teachers: how non-traditional pre-service teachers navigate their initial experiences of contemporary classrooms." Asia-Pacific Journal of Teacher Education 45 (4): 416-431. doi.org/10.1080/1359866X.2017.1312281

Darling-Hammond, L. and Bransford, J. 2005. Preparing teachers for a changing world: What teachers should learn and be able to do. San Francisco: Jossey-Bass. 
Darling-Hammond, L. 2006. “Assessing teacher education: The usefulness of multiple measures for assessing teacher outcomes.” Journal of Teacher Education 57 (2): 120-138. DOI: $10.1177 / 0022487105283796$

Darling-Hammond, L. 2017. "Teacher education around the world: What can we learn from international practice?" European Journal of Teacher Education 40 (3): 291-309.

Day, C., A. Kington, G. Stobart, and P. Sammons. 2006. “The Personal and Professional Selves of Teachers: Stable and Unstable Identities.” British Educational Research Journal 32 (4): 601-616.

Day, C., and A. Kington. 2008. "Identity, Well-being and Effectiveness: The Emotional Contexts of Teaching." Pedagogy, Culture \& Society 16 (1): 7-23. DOI: $10.1080 / 14681360701877743$

Day, C., Elliot, B., and Kington, A. 2005. "Reform, standards and teacher identity: Challenges of sustaining commitment." Teaching and Teacher Education 21 (5): 563-577. DOI:10.1016/j.tate.2005.03001

Dey, I. 1993. Qualitative data analysis: a user-friendly guide for social scientists. London: Routledge. DOI:10.1080/02619768.2017.1315399

Elo, S. and Kyngäs, H. 2008. “The qualitative content analysis process.” Journal of Advanced Nursing 62 (1): 107-115. doi: 10.1111/j.1365-2648.2007.04569.x.

Fives, H. and Buehl, M.M. 2012. "Spring cleaning for the 'messy' construct of teachers' beliefs: What are they? Which have been examined? What can they tell us?" In APA educational psychology handbook. Vol. 2: Individual differences and cultural and contextual factors, edited by K.R. Harris, S. Graham, T. Urdan, S. Graham, J.M. Royer and M. Zeichner, 471-499. Washington, DC: American Psychological Association.

Hamacheck, D. 1999. "Effective teachers: what they do, how they do it, and the importance of self-knowledge." In The role of self in teacher development, edited by R.P.Lipka and T.M Brinthaupt, 189-225. New York: State University of New York Press.

He, Y., and B. B. Levin. 2008. "Match or Mismatch: How Congruent Are the Beliefs of Teacher Candidate, Teacher Educators, and Cooperating Teachers?” Teacher Education Quarterly 35 (4): $37-55$.

Herbart, J. F. 1835. Umriss pädagogischer Vorlesungen von Johan Friedrich Herbart. Verausgegeben und mit erläuternden Anmerkungen versehen von Hermann 
Wendt [Compendium of Pedagogical Lectures by Johan Friedrich Herbart, compiled and edited by Hermann Wendt]. Leipzig: Verlag von Philipp Reclam jun

Hiebert, J., Morris, A.K., Berk, D., and Jansen, A. 2007. "Preparing teachers to learn from teaching." Journal of Teacher Education 58 (1): 47-61. DOI: $10.1177 / 0022487106295726$

Hsieh, B. 2015. "The importance of orientation: implications of professional identity on classroom practice and for professional learning." Teachers and Teaching: Theory and Practice 21 (2): 178-190. DOI:10.1080/13540602.2014.928133

Kansanen, P. 2003. "Studying - The Realistic Bridge between Instruction and Learning. An Attempt to a Conceptual Whole of the Teaching-Studying-Learning Process" Educational Studies 29 (2-3): 221-232.

Korthagen, F. 2017. "Inconvenient Truths about Teacher learning: Towards Professional Development 3.0." Teachers and Teaching: Theory and Practice 23 (4): 387-405. doi: /10.1080/13540602.2016.1211523.

Korthagen, F. 2010. "How teacher education can make a difference." Journal of Education for Teaching 36 (4): 407-423. https://doi.org/10.1080/02607476.2010.513854

Kostiainen E., Ukskoski, T., Ruohotie-Lyhty, M., Kauppinen, M., Kainulainen, J. and Mäkinen T. 2018. "Meaningful learning in teacher education." Teaching and Teacher Education 71 (April): 66-77. doi:10.1016/j.tate.2017.12.009

Levin, B.B., He, Y., and Allen, M.H. 2013. "Teacher beliefs in action: A cross-sectional, longtitudinal follow-up study of teachers' personal practical theories." The Teacher Educator 48 (3): 201-217. doi.org/10.1080/08878730.2013.796029

Lunenberg, M., and F. Korthagen. 2009. "Experience, Theory, and Practical Wisdom in Teaching and Teacher Education." Teachers and Teaching: Theory and Practice 15 (2): 225-240. doi: /10.1080/13540600902875316.

Maaranen, K., Pitkäniemi, H., Stenberg, K., \& Karlsson, L. 2016. “An idealistic view of teaching: teacher students' personal practical theories." Journal of Education for Teaching 42 (1): 80-92. doi: 10.1080/02607476.2015.1135278

Maaranen, K. and Stenberg, K. 2017. 'Portraying Reflection: The contents of student teachers' reflection on personal practical theories and practicum experience." Reflective Practice 18 (5): 699-712. https://doi.org/10.1080/14623943.2017.1323729 
Maclellan, E. 2017. "Shaping agency through theorizing and practicing teaching in teacher education." In The SAGE Handbook of Research on Teacher Education, edited by D.J Clandinin and J. Husu, 253-269. London: Sage Publications.

Nickel, J. and Zimmer, J. 2018. "Professional identity in graduating teacher candidates." Teaching Education 30 (2): 149-159. doi.org/10.1080/10476210.2018.1454898

Niemi, H., Toom, A. and Kallioniemi, A. (Eds.) 2016. Miracle of education: The principles and practices of teaching and learning in Finnish schools. ( $2^{\text {nd }}$ Revised Edition). Rotterdam/Taipei/Boston: Sense Publishers.

Pantic, N. and Wubbels, T. 2010. "Competence-based teacher education: A change from Didaktik to curriculum culture?.” Journal of Curriculum Studies 44 (1): 61-87. doi.org/10.1080/00220272.2011.620633

Pantic, N., Wubbles, T., and Mainhard, T. 2011. "Teacher competence as a basis for teacher education: Comparing views of teachers and teacher educators in five Western Balkan countries." Comparative Education Review 55 (2): 165-188.

Pennington, M. C. and Richards, J.C. 2016. "Teacher Identity in Language Teaching: Integrating Personal, Contextual, and Professional Factors." RELC Journal 47 (1): 5-23. DOI: $10.1177 / 0033688216631219$

Prilop, C. N., Weber, K. E. and Kleinknecht, M. 2019. "How digital reflection and feedback environments contribute to pre-service teachers' beliefs during a teaching practicum." Studies in Educational Evaluation 62: 158-170. https://doi.org/10.1016/j.stueduc.2019.06.005

Richardson, V. 1996. "The role of attitudes and beliefs in learning to teach." In Handbook of research on teacher education, edited by T.J. Buttery, E. Guyton, and J.P. Sikula, 201119. New York: Macmillan.

Richardson, V. 2003. "Preservice teachers' beliefs.” In Teacher beliefs and classroom performance: The impact of teacher education, edited by J. Raths and A. McAninch, 122. Charlotte, NC: Information Age.

Rodgers, C. R., and Scott, K. H. 2008. "The Development of the Personal Self and Professional Identity in Learning to Teach." In Handbook of research on teacher education ( $3^{\text {rd }} \mathrm{ed}$.), edited by M. Cochran-Smith, S. Feiman-Nemser, D. J. McIntyre, and K. E. Demers, 732755. New York: Routledge. 
Sachs, J. 2005. "Teacher Education and the Development of Professional Identity: Learning to be a Teacher." In Connecting Policy and Practice: Challenges for Teaching and Learning in Schools and Universities, edited by P. Denicolo and M. Compf, 5-21. Oxford: Routledge.

Sahlberg, P. 2011. Finnish Lessons: What Can the World Learn from Educational Change in Finland? New York: Teachers College Press.

Sanger, M.N. 2017. "Teacher Beliefs and the Moral Work of Teaching in Teacher Education” in The Sage Handbook of Research on Teacher Education, Vol 1, edited by Clandinin, D.J. and Husu, J., 239-353. London: Sage.

Shulman, L.S. 1986. “Those Who Understand: Knowledge Growth in Teaching.” Educational Researcher 15: 4-14.

Shulman, L.S. 1987. "Knowledge and teaching: Foundations of the new reform." Harvard Educational Review 57 (19): 1-22.

Stenberg, K. 2011. Working with Identities. Promoting Student Teachers' Professional Development. Juva: University of Helsinki, Faculty of Behavioural Sciences, Department of Teacher Education.

Stenberg, K. and Maaranen, K. 2020. "The differences between first year and fourth year student teachers' teacher identity based on their practical theories.” Education Inquiry. DOI: 10.1080/20004508.2020.1716541

Stenberg, K., H. Pitkäniemi, L. Karlsson, and K. Maaranen. (2014). Beginning student teachers' teacher identities based on their practical theories." European Journal of Teacher Education, 37, 2, 204-219. https://doi.org/10.1080/02619768.2014.882309

Tilson, J., Sandretto, S. and Pratt, K. 2017. "Connecting theory to practice: Using preservice teachers' beliefs, theories and video-recorded teaching to prompt a cycle of praxis." Teaching and Teacher Education 67: 454-463. doi: 10.1016/j.tate.2017.07.012

Tirri, K. 2014. “The last 40 years in Finnish teacher education.” Journal of Education for Teaching 40 (5): 600-609. DOI:10.1080/02607476.2014.956545

Toom, A., Husu, J., and S. Patrikainen. 2015. "Student teachers' patterns of reflection in the context of teaching practice.” European Journal of Teacher Education 38 (3): 320-340. DOI: $10.1080 / 02619768.2014 .943731$ 
Trent, J. 2011. “'Four Years on, I'm Ready to Teach': Teacher Education and the Construction of Teacher Identities." Teachers and Teaching 17 (5): 529-543. doi.org/10.1080/13540602.2011.602207

Varghese, M., B. Morgan, B. Johnston, and K. A. Johnson. 2005. "Theorizing Language Teacher Identity: Three Perspectives and beyond." Journal of Language, Identity \& Education 4 (1): 21-44. doi.org/10.1207/s15327701jlie0401_2 


\section{Tables and figures}

Figure 1. Relationships in the extended didactic triangle from a teacher's viewpoint (cf. Author $2,2011)$

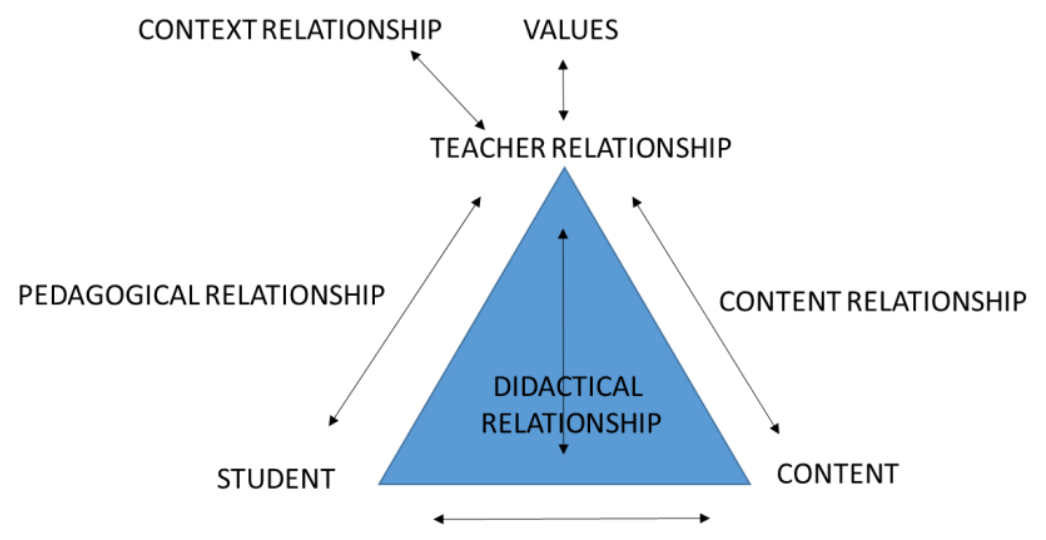

Table 1. Background information of the participants

\begin{tabular}{|c|c|c|c|c|}
\hline & Subject & Gender & Basic Practicum (fall 2015) & $\begin{array}{l}\text { Advanced Practicum (spring } \\
\text { 2016) }\end{array}$ \\
\hline $\begin{array}{l}\text { Student } \\
1\end{array}$ & $\begin{array}{l}\text { Finnish as a } \\
\text { Second } \\
\text { Language }\end{array}$ & $\mathrm{F}$ & $\begin{array}{l}14 \text { lessons (most } 45 \\
\text { minutes, some } 75 \text {-minute } \\
\text { lessons) } \\
\text { Elementary \& middle } \\
\text { school }\end{array}$ & $\begin{array}{l}11 \text { lessons } \\
\text { Middle school }\end{array}$ \\
\hline $\begin{array}{l}\text { Student } \\
2\end{array}$ & Physics & $\mathrm{F}$ & $\begin{array}{l}8 \text { lessons }+1 \text { co-taught with } \\
\text { the supervisor } \\
\text { Middle school }\end{array}$ & $\begin{array}{l}8 \text { lessons } \\
\text { High school } \\
\text { Teaching alone }\end{array}$ \\
\hline
\end{tabular}




\begin{tabular}{|c|c|c|c|c|}
\hline $\begin{array}{l}\text { Student } \\
3\end{array}$ & Physics & $\mathrm{F}$ & $\begin{array}{l}8 \text { lessons } \\
\text { Middle and high school }\end{array}$ & $\begin{array}{l}8 \text { lessons } \\
\text { Middle and high school }\end{array}$ \\
\hline $\begin{array}{l}\text { Student } \\
4\end{array}$ & $\begin{array}{l}\text { English } \\
\text { Language }\end{array}$ & $\mathrm{F}$ & $\begin{array}{l}10 \text { lessons } \\
\text { Middle school }\end{array}$ & $\begin{array}{l}8 \text { lessons } \\
\text { Middle school }\end{array}$ \\
\hline $\begin{array}{l}\text { Student } \\
5\end{array}$ & Biology & $\mathrm{F}$ & $\begin{array}{l}8 \text { lessons } \\
\text { Middle school }\end{array}$ & $\begin{array}{l}8 \text { lessons } \\
\text { Middle school }\end{array}$ \\
\hline $\begin{array}{l}\text { Student } \\
6\end{array}$ & $\begin{array}{l}\text { French } \\
\text { Language }\end{array}$ & $\mathrm{F}$ & $\begin{array}{l}8 \text { lessons } \\
\text { Middle and high school }\end{array}$ & $\begin{array}{l}6 \text { lessons }+2 \text { exam lessons } \\
\text { (preparing and holding an } \\
\text { exam) } \\
\text { Junior and senior high } \\
\text { school }\end{array}$ \\
\hline $\begin{array}{l}\text { Student } \\
7\end{array}$ & $\begin{array}{l}\text { Religious } \\
\text { Education }\end{array}$ & $\mathrm{F}$ & $\begin{array}{l}8 \text { lessons } \\
\text { Middle school }\end{array}$ & $\begin{array}{l}9 \text { lessons } \\
\text { Middle school }\end{array}$ \\
\hline $\begin{array}{l}\text { Student } \\
8\end{array}$ & $\begin{array}{l}\text { Physics } \\
\text { Mathematics }\end{array}$ & $\mathrm{M}$ & $\begin{array}{l}4 \text { lessons mathematics, } \\
4 \text { lessons physics } \\
\text { Middle \& high school }\end{array}$ & $\begin{array}{l}\text { (spring 2017) } \\
4 \text { lessons mathematics, } \\
4 \text { lessons physics } \\
\text { Middle \& high school }\end{array}$ \\
\hline $\begin{array}{l}\text { Student } \\
9\end{array}$ & $\begin{array}{l}\text { Mathematics, } \\
\text { ICT }\end{array}$ & $\mathrm{M}$ & $\begin{array}{l}8 \text { lessons (total) } \\
\text { Mathematics \& ICT } \\
\text { Middle and high school }\end{array}$ & $\begin{array}{l}\text { (spring 2017) } \\
8 \text { lessons (total) } \\
\text { Mathematics \& ICT } \\
\text { Middle and high school }\end{array}$ \\
\hline $\begin{array}{l}\text { Student } \\
10\end{array}$ & $\begin{array}{l}\text { Finnish } \\
\text { Language } \\
\text { (Mother } \\
\text { Tongue) }\end{array}$ & $\mathrm{F}$ & $\begin{array}{l}7 \text { lessons alone } \\
\text { Middle and high school }\end{array}$ & $\begin{array}{l}\text { (spring 2017) } \\
8 \text { lessons } \\
\text { Middle and high school }\end{array}$ \\
\hline
\end{tabular}

Table 2. Relations and their changes 


\begin{tabular}{|l|l|l|l|}
\hline Relation & $\begin{array}{l}\text { At the beginning of } \\
\text { studies }\end{array}$ & $\begin{array}{l}\text { In the middle of } \\
\text { studies }\end{array}$ & Change in relation \\
\hline $\begin{array}{l}\text { Self-awareness } \\
\text { (Teacher relation) }\end{array}$ & $\begin{array}{l}22 \text { beliefs of } 78 \\
28.29 \%\end{array}$ & $\begin{array}{l}17 \text { beliefs of } 51 \\
33.3 \%\end{array}$ & $+4.4 \%$ \\
\hline Content relation & 5 beliefs of 78 & 2 beliefs of 51 & $-2.49 \%$ \\
\hline Didactical Relation & $6.41 \%$ & $3.92 \%$ & \\
\hline Pedagogical & $\begin{array}{l}15 \text { beliefs of } 78 \\
19.23 \%\end{array}$ & 8 beliefs of 51 & $-3.54 \%$ \\
\hline Relation & 33 beliefs of 78 & $15.69 \%$ & \\
\hline Context relation & $42.31 \%$ & $29.41 \%$ & $-12.9 \%$ \\
\hline & 3 beliefs of 78 & 9 beliefs of 51 & $+13.8 \%$ \\
\hline & $3.85 \%$ & $17.65 \%$ & \\
\hline
\end{tabular}

Figure 2. The realization of the PPTs in the Basic Practicum according to the didactic triangle

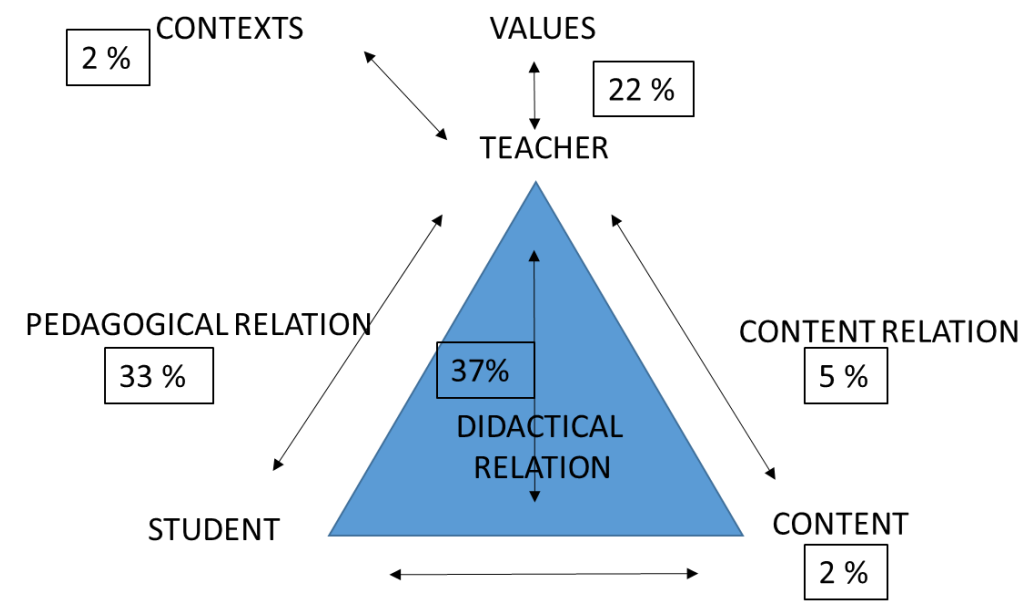

Figure 3. The realization of the PPTs in the Advanced Practicum according to the didactic triangle. 


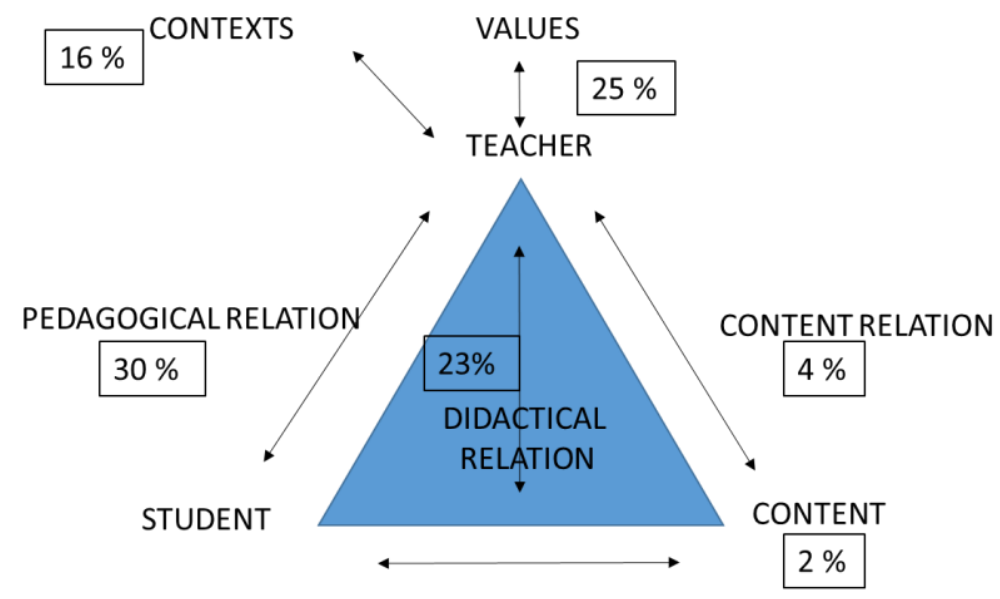

